\title{
脂肪エマルジョンの皮膜形成に関与できる 牛乳蛋白質について
}

\author{
伊藤僘敏, 中西武雄 \\ （東北大学農学部畜虐利用学教室） \\ 昭和 48 年 10 月 3 日受理
}

\begin{abstract}
On the Milk Protein Fractions Contributing to Make Fat Globule Membrane of Fat Emulsion

By Takatoshi ITOH and Takeo NAKANISHI

Laboratory of Animal Products Technology, Faculty of Agriculture, Tohoku University, Sendai
\end{abstract}

The milk protein components contributing to make stable fat emulsion by adsorbing on the fat globule when fat was emulsified in milk were separated and examined electrophoreticaly.

The fat globule membrane material (F.G.M.) from homogenized raw milk contained more milk protein components than F.G.M. from original milk, though its proportion differed by the extent of homogenization.

Fat emulsifying material (F.E.M.) obtained by emulsifying butter fat in casein solution was composed mainly from TS- and $\gamma$-casein. $\alpha_{s^{-}}$and $\beta$-casein were also involved when homogenized extremely. Para $\kappa$-casein was main component of F.E.M. from casein solution treated with rennet. F.E.M. from acid whey and rennet whey was constituted mainly from $\beta$-lactoglobulin and immune globulin. These components of F.E.M. from casein and whey differed according to the method and the extent of emulsification and the amount of fat added.

Emulsifying capacity of casein solution compared by extraction of free fat with petroreum ether was decreased by treatment with rennet, addition of $\mathrm{Ca}$ ion and lowering of pH. Rennet whey showed higher emulsifying capacity than acid whey when small amount of fat was emulsified.

(Received October 3, 1973)

\section{緒 言}

牛乳中に存在する脂肪は脂肪球膜によってつつまれ， 安定なエマルジョンとして分散している。このよらな脂 肪球膜 (F. G. M.) の由来については多くの研究が行なわ れた結果，それが乳腺細胞の細胞膜や細胞質より構成さ れていることが明らかにされてきた(1)。また最近の研究 では，特に細胞膜と脂肪球膜成分の類似性の高いことが 報告されている(2,3).

ところで牛乳脂肪を均質化によって微細粒子とした場 合，脂肪球の表面積が増大するのにともなって，本来の 脂肪球膜成分に加えて，新たに牛乳中の蛋白質などが加
わって表面を和和ら膜成分を形成し，安定な乳化状態の 保たれることが知られて和り，このときカゼインやホエ 一蛋白質の一部が関与すると考它られている(4)，また一 方，脱脂乳やホエーに脂肪を添加して均質化させた場合 にも十分に安定な乳濁液を得ることができ，この場合に も牛乳蛋白質の一部が分散された脂肪の表面に分布し

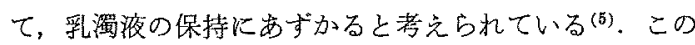
ように一部の牛乳蛋白質は，脂肪を乳化させた場合本来 の脂肪球膜と同様に，乳渭液を安定に保持与る效果をる っているが，どのような成分が效果をるたらすかについ てはまた十分知られていないので，本報告では皮膜成分 として関与してくる成分のうち，特に蛋白質成分につい 
て調ベた。

\section{実 娩 方，法}

1. 脂肪球膜物澌 (F.G.M.) の調製法 牛乳上り の F.G.M. の調製は Fig. 1 と示すような方法に従って 行なった，カゼイン溶液あるいはホエーに脂肪を加えて 乳化した試料よりの F.G.M. の調製も，同じ方法で行 なった．電気泳動的研究を主目的としたため，脂質の抽 出はへキサンを用いて行なった。

2. カゼイン溶液の調製およびレンネット処理 脱 脂乳に $0.1 \mathrm{~N} \mathrm{HCl}$ を加兄て $\mathrm{pH} 4.6$ でカゼインを等䉓点 沈㔀させ，水洗後溶解，沈殷の操作を 1 回くりか古した のち， $0.1 \mathrm{~N} \mathrm{NaOH}$ で溶解し $\mathrm{pH} 4.6$ の溶液とした. ケ ルダール法により窒素含量を测定し，必要濃度に希䣋し て使用した、レンネット処理は，カゼイン溶液にレンネ ッ上粉末 (ハンゼン社製) の水溶液を，濃度が $0.01 \%$ K なるように加亲て $35^{\circ} \mathrm{C}$ 飞 15 分間保持したのち， $80^{\circ} \mathrm{C}$ の湯浴中で 10 分間加熱して行なった。

3. 酸ホエーおよびレンネットホエーの調製 酸ホ エーは，試薬添加による彩を少なくするために，脱脂 乳に $2 \mathrm{~N} \mathrm{HCl}$ を加えて $\mathrm{pH} 4.6$ でカゼインを沈殿させて 分離し， $2 \mathrm{~N} \mathrm{NaOH}$ により $\mathrm{pH}$ を 6.7 亿調整したものを 使用した.レンネットホエーは，脱脂乳にレンネット粉 末（ハソゼン社製）の水溶液を濃度が 0.01\%になるよう に加光， $35^{\circ} \mathrm{C}$ 江 15 分間保ってカゼインを凝固させて調 製した。

4. 均質化の方法 均質機を用いて均質化を行なら 場合には，三丸製作所製小型ホモジナイザーH 10 型を 使用し， $50^{\circ} \mathrm{C}$ 飞加温して $150 \mathrm{~kg} / \mathrm{cm}^{2}$ の圧力で行なっ

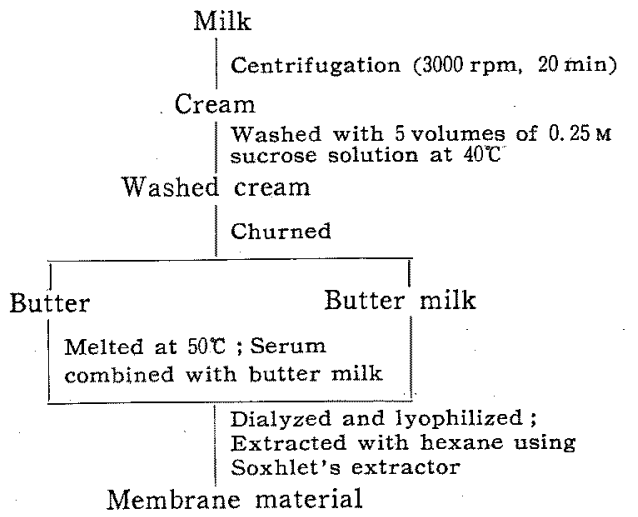

Fig. 1. Procedure for the Isolation of Fat Globule Membrane Material.
た．脂肪を添加する試料の場合には，ミキサーであらか じめ擤汼して脂肪を分散させたのち均質機に通した。

5. デンプンゲル電気泳動法 Schmidt( ${ }^{(6)}$ の方法に

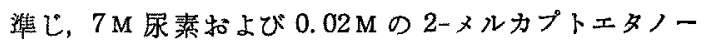

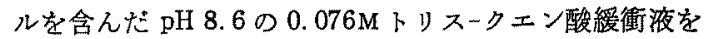
電極液として用いて行なった，泳動後ゲルをアミドブラ ック10Bによって染色した。

6. カゼインのクロロホルム・メタノールによる抽出 酸沈殷させた湿カゼインに，クロロホルム・メタノール (2:1)を加党てはげしく靦拌して 2 回抽出し, 溶媒相に $1 / 5$ 量の水を加え，上層と中間層を取り，水に対して透 析したのら濃縮して涷結乾燥した。

7. 乳化力の測定法 カゼイン溶液またはホエー

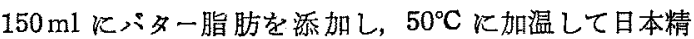
機製撜拌式ホモジナイザー HC 型を用い，18,000rpm で 60 秒間霓䢁する. $60^{\circ} \mathrm{C}$ の湯浴中に 30 分間保持したの ち $3000 \mathrm{rpm}$ で 15 分間遠心分離する. クリーム層をビー カーにとり，石油エーテル (45〜60 $\mathrm{C}$ 留分) $20 \mathrm{ml}$ を加

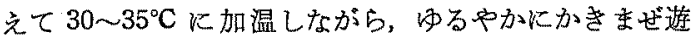
離脂肪を抽出する. $20 \mathrm{ml}$ ずつを用いて 4 回抽出をくり がし，遠沈管内も石油エーテルで洗って全抽出夜を合 わせ，溶媒を留去する，抽出された脂肋量を科量して， 添加した全脂肪量に対する抽出された遊離脂肪量の割合 を求め, 乳化力とした。

\section{実 験 結 果}

\section{1. 牛乳の F. G. M. の組成}

牛乳より分離した F.G.M. の組成と，之の均質化炕 よる変化等をデンプンゲル電気泳動法によって調べた結 果は，Fig. 2 に示すと括りである。

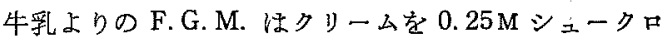
一ス液で 3 回洗浄した段階 (c)では $\alpha_{s}$ や $\beta$-カゼインが 含むれているが，6 回洗浄すると(d)このような成分は 漂とえど除去され，7M 尿素に可溶の泳動性成分が少な くなり，原点にとどをる成分が大部分をしめるようにな る，ここで残った成分が，特に細胞膜由来の成分之考兄 られる．原料乳を $150 \mathrm{~kg} / \mathrm{cm}^{2}$ で2 回均質化したのち分 離した F.G.M.の組成は，クリ一ムの洗浄回数が３回 の場合には（e），やはりカゼインが含まれているが，6 回洗浄後で性 $(f)$ こ礼らの成分はごく少量となる..しか し，均質化しない牛乳上りの F. G. M. 飞比較して，可 溶性で泳動性のある成分が增加することが認められた。 


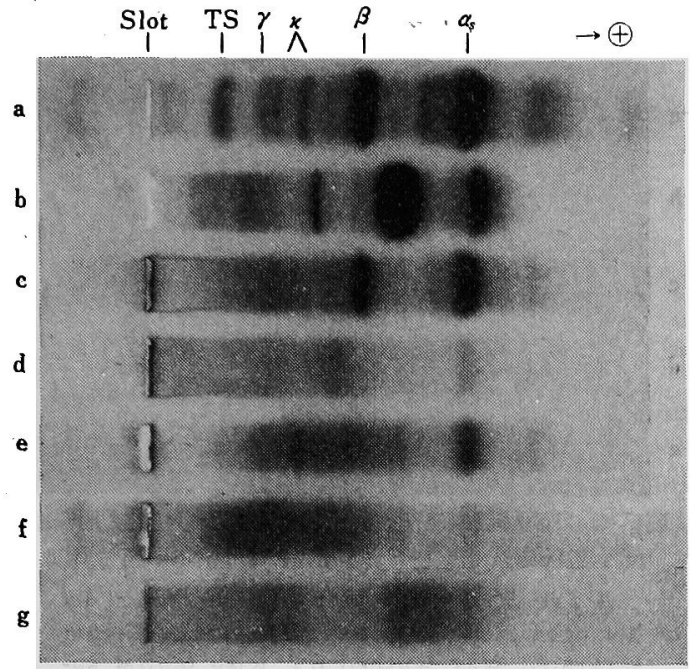

Fig. 2. Starch Gel Electrophoresis of Fat Globule Membrane Material (F.G.M.) from Raw Milk and Homogenized Milk.

a : whole casein, b : whole whey protein, c: F.G.M. from raw milk, washed $3 \times$, d : F.G.M. from raw milk, washed $6 \times$, e : F.G.M. from raw milk homogenized $2 \times$ at $150 \mathrm{~kg} / \mathrm{cm}^{2}$, washed $3 \times$, $\mathrm{f}:$ the same as e, washed $6 \times, g$ : the same as $e$, homogenized $6 \times$, washed $6 \times$.

均質化の回数を増すと $(\mathrm{g})$ ，その成分には，さらに $\alpha_{s^{-}}$ カゼインや $\beta$ ラクトグロブリンの一部とみられる易動 度の高い成分が加わり，可溶性区分のいっそう増加する ことが認められた. このような成分の増加は，牛乳蛋白 質の一部が，均質化によって表面積の増加した脂肪球の 皮膜形成にあずかっていることを示している.

2. カゼインおよびホエー中の脂肪乳化成分について カゼイン溶液にハター脂肪を加えて均質化した乳濁液 より分離した皮膜物質（以下牛乳中の本来の F. G. M. と 区別して，脂肪乳化成分 F.E.M. と表示する）につい ての結果は Fig. 3 に示す.

$\mathrm{pH} 6.7$ の0.5\% Na-カゼイン溶液に $5 \%$ の ハ ター脂 肪を加え, $150 \mathrm{~kg} / \mathrm{cm}^{2}$ で2回均質化して得たエマルジ ョンから，牛乳の F.G. M. 調製法に準じて分離した F. E.M. は，cに示すように，主としてTS-カゼインおよ び の成分がカゼイン中です特に脂肪表面に吸着されやすい ことが知られた.レンネット処理をしたNa-カゼイン溶 液を用いて同様な串験をした場合には， $\mathrm{d}$ に示すように F.E.M. 中にパラ ハーカゼインが多量に含まれてきた.

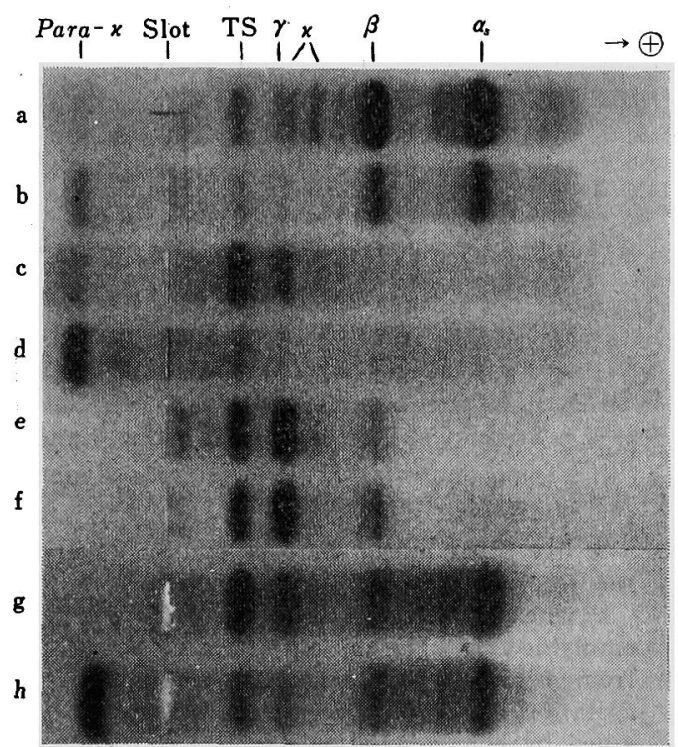

Fig. 3, Starch Gel Electrophoresis of Fat Emulsifying Material(F.E.M.)from Casein Solution.

A five $\%$ of butter fat was emulsified in the casein solutions of $\mathrm{pH} 6.7$ by homogenization at $150 \mathrm{~kg} / \mathrm{cm}^{2}$. Cream separated was washed $6 \times$ with $0.25 \mathrm{M}$ sucrose solution. $\mathrm{a}$ : whole casein, $\mathrm{b}$ : whole casein treated with rennet, c: F.E.M. from $\mathrm{Na}$-caseinate solution, homogenized $2 \times$, d : F.E.M. from $\mathrm{Na}$-caseinate solution treated with rennet, homogenized $2 \times$, e : chlorohorm-methanol (2:1) extractable fraction from whole casein, f : chloroform-methanol (2:1) extractable fraction from whole casein treated with rennet, $g$ : the same as $c$, homogenized $6 \times, h$ : the same as $d$, homogenized $6 \times$.

次に,これら両試料について均質化処理を 6 回行なった 場合の F.E. M. の組成は， g 拈よび h に示すか， 2 回の

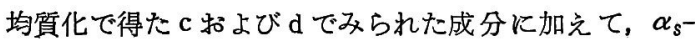
および $\beta$-カゼインならびにその中間に泳動する微量の カゼイン成分が含まれてくることが認められた．な持均 質化の回数が少ない場合でる，脂肪量を増加すると同様 な傾向のみられることを観察して扣り，脂肪の表面積が 特に増加した場合には， $\alpha_{s^{-}}$や $\beta$-カゼインの一部 る， F.E.M.として関与するものと考学られた.

一方, 牛乳やカゼインをクロロホルム・メタノール (2：1)で抽出すると, カゼインの一部が溶出してくるこ とが Cerbulis ら (7 9)によって認められている.この成 分は e に示すように，主として TS- 怙よび $r$ カゼイン からなって拈り，cに示される F.G.M. と類似してい 


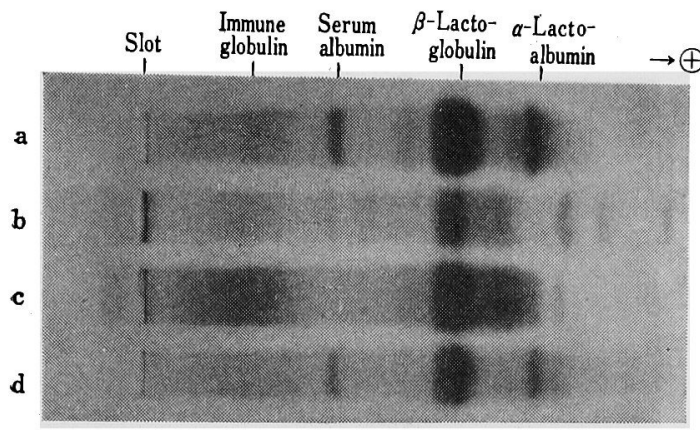

Fig. 4. Starch Gel Electrophoresis of Fat Emulsifying Material (F.E.M.) from Rennet Whey and Acid Whey.

A five $\%$ of butter fat was emulsified in the whey of $\mathrm{pH} 6.7$.

a: whey protein, b: F.E.M. from acid whey emulsified by vigorous agitation, c: F.E.M. from rennet whey emulsified by vigorous agitation, d: F.E.M. from rennet whey emulsified by homogenization $6 \times$ at $150 \mathrm{~kg} / \mathrm{cm}^{2}$.

た.な括レンネットカゼインからはパラ $\kappa$ ーカセ゚インは 溶出されてこなかった（f）。

次に，酸ホェー浐よびレンネットボェーにバター脂肪 を加えて乳化させた場合の F.E.M. の組成は，Fig. 4 に 示すと括りである. まず dに示するらに，レンネットホ エーに脂肪を加えて $150 \mathrm{~kg} / \mathrm{cm}^{2}$ で 6 回の均質化処理を 行なった場合の F.E.M. は，主要なホェー蛋白質成分 のすべてを含んでいることが認められた．この場合，均 質化の過程に扮いて試料溶液が次第に白濁し，ホエー蛋 白質の凝固するのが認められ，このような機械的な処理 によって不溶性となったホエー蛋白質の一部が脂肪に吸 着してくることが考えられたので，次に均質機を用小な いで覚找器 (日本精機製ホモジナイザー HC 型) により, $18,000 \mathrm{rpm}$ で覚找することによって乳化させた乳濁液 より分離した F.E.M.は， b 括よびcに示すと拈りで ある. bは $\mathrm{pH} 6.7$ の酸ホエー, c はレンネットホエー を用いたものであるが，いずれも免疫グロブリン括よび $\beta$-ラクトグロブリンを主成分とし，さらに $\beta$-ラクトグ ロブリンよりも易動度の高い微量の数成分よりなって拉 り， $\alpha$-ラクトアルブミンや血清アルブミンは含まれて こなかった．微量成分はホエー蛋白質中に本来含まれて いる成分か，処理によって生じたるのかは不明である。 な拝酸ホエーを用いた場合，レンネットホエーに比較し て脂肪の乳化状態がこわれやすく，クリームの洗浄中 飞脂肪が次第に塊状を呈した:，また，酸ホエーよりの

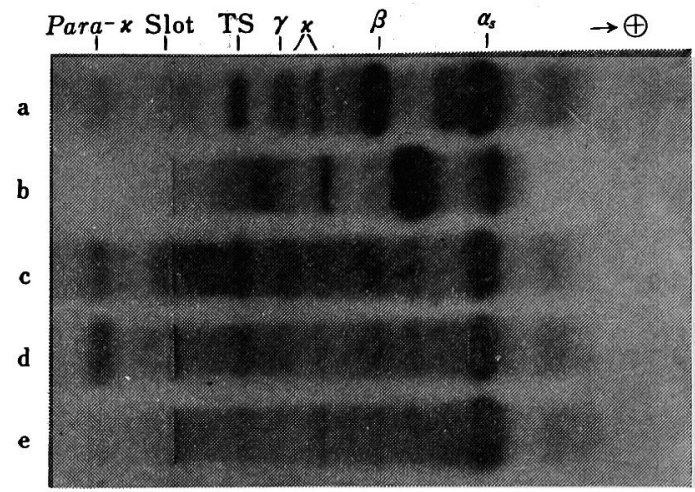

Fig. 5. Starch Gel Electrophoresis of Fat Emulsifying Material(F.E.M.)from Skim Milk.

A five $\%$ of butter fat was emulsified by homogenization $3 \times$ at $150 \mathrm{~kg} / \mathrm{cm}^{2}$. Cream separated was washed $6 \times$ with $0.25 \mathrm{M}$ sucrose solution.

a : whole,casein; b : whole whey protein, c: F. E. M. from skim milk, d: F. E. M. obtained by reemulsifying in the liquid phase from c, e : F. E. M. obtained by reemulsifying in the liquid phase from $d$.

F.E.M. 中には, $7 \mathrm{M}$ 尿素に不溶性で非泳動性の成分が かなり含まれているのが認められた。

脱脂乳に脂肪を加えて乳化させた場合の F. E. M. の 組成は，Fig. 5 に示すとおりである．この場合，脱脂乳 に $5 \%$ のパター脂肪を加えて $150 \mathrm{~kg} / \mathrm{cm}^{2}$ で 3 回均質化 したのち，遠心分離によってクリームを分離し，液相中 に新たに $5 \%$ の バター脂肪を加えて均質化してクリーム を分離するといった操作を 3 回くりかえして得たりリ一 ムを，それぞれ6回洗浄して F.E.M. を分離した.

いずれの場合も F. E. M. の組成は類似して特り； $\alpha_{s^{-}}$,

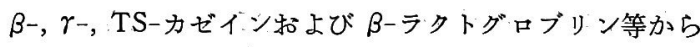
構成されているのが認められたが，初回では: TS-カゼ インが比較的多く：回数が増すにつれて $\alpha_{s^{-}}$ガインの 割合が高くなる傾向にあった. ，また 2 回までの F. E. M.

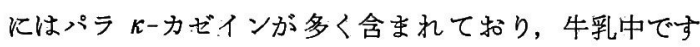
でに $\kappa$-カゼインの分解により生じていたものが吸着さ れたものと思われる。

\section{3. 乳化力の比較}

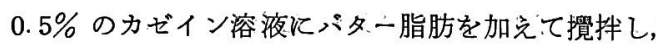
石油エーテルで抽出される脂肪量を求め, 添加した脂肪 量に対する割合によって乳化力を比較した結果は Fig.6 に示すと物りである，Na-カゼイン溶液の場合には，脂 肪添加量が $20 \%$ までは遊離の脂肪量が少なく，上く乳 


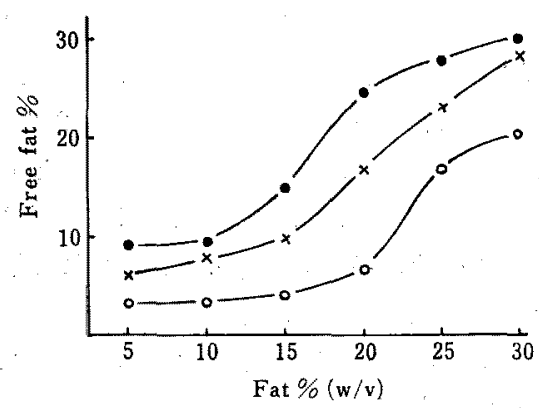

Fig. 6. Emulsifying Ability of Casein Solution.

Butter fat was emulsified by vigorous agitation in $0.5 \%$ casein solution of $\mathrm{pH} 6.7$.

O Na-caseinate, $\times$ Ca-caseinate (Ca, 25 $\mathrm{mg}$ ), $\mathrm{Na}$-caseinate treated with rennet.

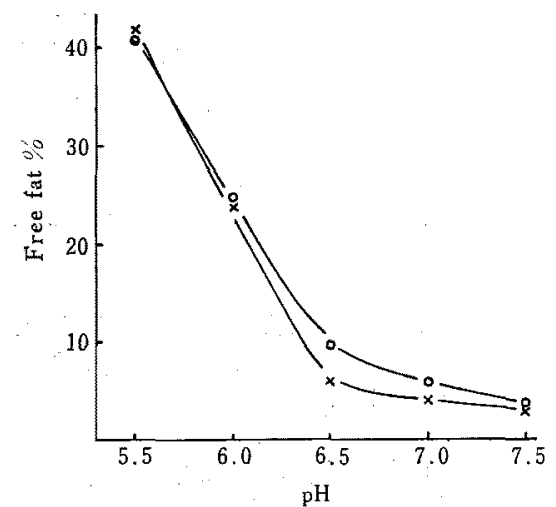

Fig. 7. Effect of pH on the Emulsifying Ability of Casein Solution.

Butter fat was emulsified by vigolous agitation in $0.5 \% \mathrm{Na}$-caseinate solution.

O $20 \%$ fat, $\times 15 \%$ fat.

化されるが，脂肪量が $20 \%$ を越えると乳化されないで 遊離状態となる脂肪量が增加してくる. $\mathrm{Ca}(\mathrm{OH})_{2}$ を用 いて溶解した Ca-カゼイン溶液 (Ca $25 \mathrm{mg} \%$ ) の場合に は, Na-カゼイン溶液に比較して乳化力が弱く，全体を 通乙て的 2 倍量の脂肪が遊離状態として抽出された。

Naーカゼイン溶液をレンネット処理して招いた場合に は, 脂肪の乳化力がさらに低下し, 遊離の脂肪量が增加 した.この場合，F.E.M.の組成は Fig. 3-dに示される ようにパラ ンネット好理によって乳化力の增加することが期待され たが，逆に低下するをいった結果定した。

Fig. 7 は pH を変化させた場合の Naーカゼイン溶液の 乳化力の変化を示す： $\mathrm{pH}$ が 6.5 以下になると乳化力か゚ 急激に低下することが婆められた。

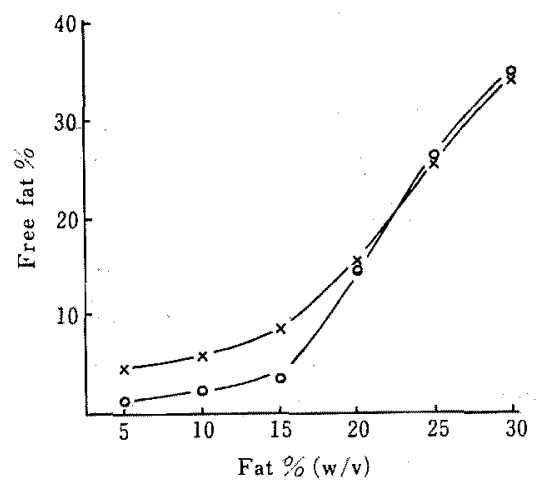

Fig. 8. Emulsifying Ability of Acid Whey and Rennet Whey,

Butter fat was emulsified by vigorous agitation in whey of $\mathrm{pH} 6.7$.

O rennet whey, $x$ acid whey.

レンネットホエーおよび酸ホエー㕝用いて，乳化力の 比較を行なった結果は Fig. 8 に示す．脂肪量が $20 \%$ 以 下の場合には，酸ホエーの方がレンネットホエーよりる。 乳化力が少し低いが，脂肪量の多い所では両者の乳化力 はほぼ同しとなる、酸ホエーの場合，カゼインを等電点 洗殿させたのち $\mathrm{pH}$ を6.7 調整してしばらく放置する と，蛋白質の一部が沈殿するのがみられるがここのため 比乳化関与しらる蛋白質量が多少低くなることが考え られる.

\section{考察}

牛乳䒚均質化した場合，得られる F.G.M. の組成は， 本来の F.G.M. のほかに表面積の増加した脂肪球の皮 膜を形成する成分として牛乳蛋白䐝の一部加関与してく ることが認められたが，去の組成性均質化の程度によっ てかなり異なってくる．ガゼインの単独溶液に脂肪を乳 化させた場合の乳化に関与する成分としては，TS- 标 よび $\gamma$ ーガインが主なものであることが認められたが， これらの成分は，またク口ロホルム・メタノールで抽出 されるカゼイン成分とも類似していることが知られた。

TSーカゼインや $\gamma$ ーカゼインは $\beta$-カゼインのフラグメン トであると考充られているが(10,11)，及一カゼインよりる りン酸基や親水性アミノ酸が少なく, 特に蹯水性の強い 性質を持って扣り，そのため脂肪球の表面強く吸着 されたり，溶媒によって抽出されるものと考觉られ，脂 肪への吸着に性特に疎水性結合が関与していると推定さ れる。

カゼイン溶液をレンネット观理して报くと，F. E. M. 
にはパラ にカガインが多量に含まれてくるが，この場 合，パラ ハーカゼインは等電点がアルカリ側にあること から，静電結合も関与していることが考えられる．しか

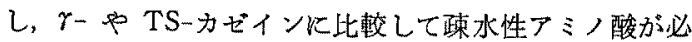
ずしも多くないこと，パラ ハーカゼイン自体が非常に凝 集しやすい性質のあることなどから考方て，脂肪に吸着 されやすいにすかかわらず，脂肪球全体を特和った形て

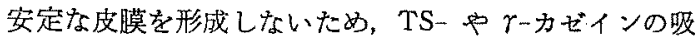
着をさまたげて，カゼインの乳化力をむしろ低下させる 原因となると考えられる。

カゼイン溶液がCaを含む場合す乳化力が低下するが， これはミセルが形成されるためにカゼイン成分の脂助球 への吸着が阻害されることによるるのと考光られる。

ホエーを用いた昜合には， $\beta$ ラクトグロブリンや免 疫グロブリンが主として乳化に関与する成分であること が認められたが，これらの成分はアルブミン系の蛋白質 に比べて比較的柾水性が強いため，脂肪に吸着されやす いものと考えられる．な特過度の均質化や加熱によって 小エー蛋白質が凝固した場合には，表面柾水域の增大に よって油との親和性が増し吸着されやすくなるが，この 場合は脂肪球全体をおおう皮膜として吸着されないため 安定な乳化状態が得られない，0.5\%の Na-カゼイン溶 液之ホエー（粗蛋白筫含量 $0.7 \%$ ）の乳化力を比較して みると，同じ条件下でカゼイン溶液では脂肪が $20 \%$ 程 度まで乳化されるの対し，ホエーでは 15\% 程度まで であり，注活同じ蛋白質含量に掓いてカゼインの乳化力 の方が高いといえる。

脂肪エマルジョン生成に関与する牛乳中の蛋白質成分 については以上のと括りであるが，さらに寒験条件を種 々変化させて調べた結果から，F.E.M，の組成は乳化の 条件によって非常に異なってくるものであり，脂肪の添 加量, 均質化の程度, 溶液の $\mathrm{pH}$ などを变化させると脂 肪球皮膜を形成する成分の割合が変化し，なた種々の成 分が共存する場合にも影響をらけることが観察された。

なお，牛乳以外の蛋白質の脂肪乳化力については，例 えば柴崎ら(12)は，大豆乳について調べており，やはり 特定の蛋白質が脂肪似吸着されやすいことを認めてい る.また児島(18)は，ベンゼンに対する血清や尿の蛋白 質の乳化力を比較している。

要約

牛乳を均質化すると脂肪球膜物質として，本来の膜成
分の他に牛乳蛋白質の含まれてくることが諗められた.

カゼイン溶液に脂肪を乳化させた場合，皮膜を形成す る成分としては，TS一ゃケーカゼインが和もなるのであ ることが認められたが，均質化の回数が增すと $\alpha_{\text {s }}$ 防がインも含まれてきた. レンネット処理をしたカ ゼインを用いると，パラルーカゼインか゚含まれてきた。

ホエーに脂肪を乳化させた場合には，膜成分は主とし て アーラクトグロブリンと免疫グロブリンによって構成 されていた，これら皮膜物質の組成は，脂肪を乳化させ る場合の方法や程度，脂肪の添加量などによって巽なる ことが認められた。

カゼイン溶液の乳化力を比較した結果， $\mathrm{Ca}$ を添加し たり，レンネット処理をすると乳化力が低下し，また $\mathrm{pH}$ が低くなると乳化力が著しく減少することが認めら れた、酸ホエーとレンネットホェーでは, 脂肪添加量の 少ないとき酸ホエーの方が乳化力が低かった。

(1) J. R. Brunner : "Fundamentals of Dairy Chemistry," ed. by B.H. Webb and A.H. Johnson, AVI. Pub. Co., Westport, Conn., 1965, p. 440.

(2) T. W. Keenan, D. J. Morré, D. E. Olson, W. N. Yunghans and S.Patton : J. Cell Biol., 44, 80 (1970).

(3) T.W.Keenan, D. E. Olson and H. H. Mollenhauer : J. Dairy Sci., 54, 295 (1971).

(4) R. H. Jackson! and J. R. Brunner : ibid., 43, 912 (1960).

(5) 小山 進 : 農化, 34, 912 (1960).

(6) D. G. Schmidt : Biochim. Biophys. Acta, 90, 411 (1964).

(7) J. Cerbulis: J. Agr. Food Chem., 16, 646 (1968).

(8) idem: Milchwiss., 24, 140 (1969).

(9) J. Cerbulis and J. H. Custer : J. Dairy Sci., 50, 1356 (1967).

(10) W. G. Gordon, M. L. Groves, R. Greenberg, S. B. Jones, E. B. Kalan, R. E. Peterson and R. E. Townend : ibid., 55, 261 (1972).

(11) B. Ribadeau-Dumas, G. Brignon, F. Grosclaud and J.C. Mercier : Eur.J. Biochem., 25, 505 (1972).

（12）柴崎一堆，大久保一良，佐藤隆生：食品工誌, 19, 580 (1972).

（13）照島和男: 生化学, 32, 118 (1960). 